\title{
第29回総会準備委員長特別講演要旨 教員養成と教育心理学の研究
}

\author{
藤 原 喜 悦 \\ (東京学芸大学)
}

\section{1 教育心理学の研究に対する教員飱成の立場からの 社会的要請}

\section{(1) 教員免許}

中学校教員免許法では, 教育心理学・青年心理学を一 級免許で 3 単位, 二級免許で 2 単位習得することが必要 要件になっている。この免許規定によって教職教育担当 の教官が必要となり, 多くの教育心理学研究者および発 達心理学者が出現するに到った。このことは中学校教育 の義務制およびその教員養成の開放制と深く関わってい る。すなわち多数の中学校教員が義務制によって必要と なり，その養成が教員養成大学のみならず一般大学にお いてもなされることとなり, その結果多数の教育心理学 ・発達心理学担当者が必要となり,こうした社会的要請 に応えて教育心理学者あるいは発達心理学者が活躍する ようになったのである。このように教員免許の規定の恩 恵を蒙ってわれわれは研究活動を行っているわけである が, 大学においては研究業績が強調され, また研究の自 由が重視されているので, ともすると上記のような社会 的期待や使命は忘れ去られがちである。

\section{（2）教員免許の拡大}

臨時教育審議会は最終答申を去る 8 月に行ったが, そ の中で教員の資質の向上が大きくとり上げられている。 こうした状況を踏まえ, 教員免許の基準の見直しが教育 職員養成審議会で検討され,「58年教養審答申」と現行 基準の中間を目処にした改正案が取り上げられている。 こうした論議は教師の資質向上にとって生徒指導や「道 徳」研究など教職專門科目の比重を大きくする必要があ るという考えを示しており, 教育心理学あるいは発達心 理学の研究にたずさわるわれわれにとっては深く考えざ るをえない状況にある。

すなわち今日の教育における危機的状況を示す，いじ め・校内暴力・無気力・学業不振 ・登校拒否・非行など の予防もしくは指導にとっては, 教育心理学や発達心理 学あるいはカウンセリングなどの知見や技法が必要不可 欠であり, 教員垱成の段階に掞いてこれらの基礎を修得 させておくべきだと強く要望されている。このように教 員の養成において児童・生徒理解とその指導に関して, 関連の深い心理学の修得を重視する必要性が認識される
に到ったことは大いに評価してよいが，ここでわれわれ が慎重に考虑すべきことは, 教員免許の心理学関連の基 準単位を増やしさえすれば, 児童・生徒理解が深まり, その指導がうまくいく筈だという, 安易な楽観主義に陥 ってはならないということである。

（3）教員養成における教育心理学の研究の必要性の 明確化

教育心理学に対する社会的期待は現在極めて大きくな っているが，われわれは今こそそのような期待に応える ことが出来る教育心理学の発展を図るべきであろう。現 在の状況下で教育心理学関連分野に関して単位の増加が 求められているのは, それらの修得によって児童・生徒 が示すさまざまな問題を的確に把握し，その解決を迅速 ・効果的に行うことが出来るだろうという期待があるか らであるが，こうした要請自体果たして適切であるかが まず検討されるべきである。他方児童・生徒が現に直面 しているさまざまな困難や問題を的確に発見して, その 解決を迅速に図ることができるような教育心理学関連分 野の知識や技法の有効適切な活用法を開発しなければな らない。

こうした文脈において教育心理学の関連分野の課目を 見直すならば，これまでのような知識の伝達だけでは決 してそうした要請には応えることが出来ないことが容易 に理解されよう。すなわち今眼の前にいる児童・生徒が それぞれ抱えている問題を鋭敏にキャッチして, 彼らが それぞれみずから解決していこうとするのを適切に援助 してやることが出来るようになることが求められている が, こうした要請に十分に応えられるようになるには， 臨床心理学の専門的な立場からいうと, 心理学の修士課 程を終了した後 1 年以上の実地経験を必要とする, 高度 の教育が本来的には必要欠くべからざるものであるとさ れていることを指摘しておこう。

そこでさしあたってわれわれは, 学部段階において最 小限何をどのように修得させるべきかを次に検討しなけ ればならない。学部段階において期待されることは, 心 理学の理論や臨床の技法などについての単なる知識では なくして、ひとりひとりの児童・生徒が現実に持ってい る具体的問題にアプローチしていく関わり方である。し 
たがってそのような学習は何らかの形態で実地に児童・ 生徒に接触する場を用意することなくしては, ほとんど 不可能であることはいうまでもない。換言すれば教育心 理学関連分野の学習において, 学部段階で具体的に児童 ・生徒と関わりを持つ学習活動を導入することが切望さ れよう。

教育の現場に教師として勤務するようになれば，そこ における経験を通じて児童・生徒理解を深め指導の方法 を改善していくことが出来るようになる。このような教 師の教育実践に基づく学習の重要性は高く評価されるべ きであるが，それにもかかわらず学部段階において特に 修得しておかなければならないことは一体何であるかを 改めて深く検討すべきであろう。率直にいうならば，教 育の世界においてしばしば発生し世間の批判を浴びるい わゆる不祥事の中には，ベテランといわれる教師が教育 熟心な余り問題を引き起こしてしまう場合も少なくない。 同様に現在問題になっている学業不振や無気力などに関 しても，ベテラン教師の中にも原因を子どもや親のせい にして，学習状況を子どもの立場から見ようとしない者 も決して少なくはない。こうした状況を振り返ってみる と，教育経験が長いから児童・生徒の学習指導がうまく なるというのは，単なる神話に過ぎないことが分かる。 したがって学習指導の実際についての具体的な指導の関 わり方を心理学的に検討して，いかにしてみのり豊かな 学習が可能となるかを分析出来る体験を, 学部段階にお いて持たせることが極めて重要となる。

\section{2 教員養成担当者の教育心理学の研究}

(1) 教育心理学の研究の 2 つのタイプ

教員養成を担当する人びとの心理学研究には, 次の 2 つの方向がある。その第 1 は研究者自身の学問的興味も しくは関心だけが先行し，その解明に没頭專念している 場合である。たとえば生理学的指標を用いて防御反射の 実験に熱中したり薬物の神経過程に及ぼす影響を研究し たりなど，その研究が児童・生徒の教育といかなる関係 があるかなどは全く念頭になく、ひたすら研究課題その ものの解明に没頭している場合である。このタイプの研 究は教員養成大学においては非常に優勢であり, 自然科 学の分野は勿論社会科学や人文科学の分野などにおいて も支配的である。な打教員養成が戦後になって大学レベ ルで行われるようになったのは，学生が学問研究の神髄 に触れる経験を持つことにより, 教育を主体的に受け止 め専門職として教育に自党的に関わるようになるためで あるという考え方が，こうした立場の人びとに多い。こ のような考え方に対して教育実践の場における重要な問 題を取り上げ，それらを心理学的に研究しようとする第
2 の立場の人びとがいる。そこでは教育という極めて複 雑な場における出来事は, 単純な実験室的な場面で研究 されるようなものとは全く異質であり，したがって教育 の場そのものの中で解明されなければならないと考えら れている。こうした教育実践の場における研究の独自性 を重視する立場を発展させていくと，教育心理学の研究 は極めて強い実践的性格を持つようになる。

（2）研究的興味・関心に基つく研究に対する過信

教員養成を担当している研究者が，みずからの学問的 興味や関心に基づいて研究すること自体は何ら不都合は ないが, 学生が研究のための研究として心理学の研究に 携わりさえすれば，そこで学生が身につけた研究態度が 直ちに教育実践に役立つ筈だと考えることには，重大な 危険が潜んでいるといえよう。

ここで心理学的研究と教育心理学的研究の違いを改め て検討してみると, 科学としての心理学的研究において は，研究の対象としての人間はあくまで研究者の外部に 存在するものとして捉えられているが，教育心理学の研 究においては児童・生徒は単なる客観的な存在ではなく して, 今眼の前で生活し成長しつつある絶対的な存在で あり，その進歩発展をもたらす方法を探求していく過程 の中で彼らを捉えようとしているのである。

したがって人間を対象視して客観的に操作してそこに 法則性を見出そうとする研究態度は，教育実践の中での 人間研究とは時には大きな食い違いがあることを明確に 認識しなければならない。これまでの教育心理学の研究 においては，科学性にともするとこだわり過ぎて児童・ 生徒の実存性を見失い, ときにはモルモット扱いに近い 取り扱いをして来たことも少なからずあった。

こうした誤った研究態度が十分検討されずに教育心理 学の研究分野に取り入れられるならば，研究になまじ触 れたり参加したりすることはかえって人間理解を歪めた り，あるいは不適切な取り扱い方を身につけさせてしま うであろう。科学的心理学を主張する人びとの中には, そこに潜んでいる哲学を十分吟味することなく，客観的 に人間を研究することだけが正しいと無条件的に信じこ み，そうしたアプローチが時には予想外の悪影響と不幸 とを子どもたちに与えていることに気づこうとしない場 合が少なくない。

\section{（3）実践的研究に対する過信}

実践研究においては研究者の教育的意図あるいは研究 に対する思い入れが強すぎて，児童・生徒の現実に関わ りなく，期待される行動をあたかも教育指導そのものの 結果であるがごとくに思い込んでしまう場合が多い。し たがってそこに報告された実践が研究者の主観的な感想 だったり期待であったりして，子どもをとりまく具体的 
状況における行動の展開を示すものではないために, 読 者が理解に苦しめられる場合が少なくない。こうしたこ とは実は研究論文の記述の在り方の欠陷だけではなくて, 研究そのものに内在している欠陥であると考えられる。 すなわち教育実践は複雑極まりない事象であり規定要因 を予め明確に設定しがたいにもかかわらず，研究者は自 分にとって切実な要因をまずとりあげて，それと予想さ れる行動変容とを短絡的に関連させてしまうという, い わば選択的認知に陥りやすい。こうした研究者自身の中 にある力強い認知傾向のために実践研究は意識的・無意 識的に歪曲され, 意図においては素晴らしい長所を持っ ているにもかかわらず実際的には必ずしも見るべき成果 をあげていない場合が多い。

このような欠陥を克服するには，まず実践研究の相互 主観性を意図的に高めるように努力する必要がある。す なわちこれからの実践研究においては，研究者および教 育実践者の協力を得て, 研究を遂行する人びとが意図し 実行する研究について絶えず批判を求め, 研究結果につ いての考察もしくは解釈に関しても率直な意見を求める ことが肝要である。

\section{3 教員養成学部における研究指導}

(1) 研究指導に対する評価

教員養成学部の学生の教育心理学研究として, しばし ば卒業論文が作成されている。一般に教員養成学部のカ リキュラムは過密であり，とくに教育実習の期間が長い ので, 卒業論文の研究には十分な時間を当てることが困 難であるが，それにもかかわらず卒業論文の作成によっ て多くの学生は心理学の研究の在り方に触れ, 専門性を 身につけたという自信を持つようになる。

教員養成担当者の研究には 2 つのタイプがあるように, 学生の研究課題の設定にも研究指向と実践指向との $2 つ$

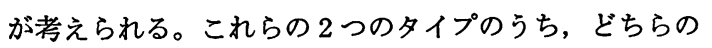
研究が教員養成学部の学生として望ましいかは容易には 決めかねるが，いずれにせよ将来教師として児童・生徒 の指導に当たるとき, 学部の段階において体験した研究 の在り方が積極的に役立つことが望ましい。しかるに指 導に当たるわれわれは, 必ずしもこのようなことを明確 に意識してはいない。勿論立派な研究論文を作成すれば 将来教師として教育実践に当たるとき, 研究体験は必ず 役に立つという信念ともいうべきものはあるが, 実際に 何がどのように役立つかについては十分な実証的裏付け がない。したがって教員養成の立場から卒業論文の研究 の在り方が, 将来の教育実践とどのように関連するかを 理論的・実証的・事例研究的に研究して, そこで明らか にされた視点に基づいて卒業論文の評価の観点を設定し
ていくことが望まれよう。

（2）実践の場における教育心理学の研究の基礎とし ての研究

教育心理学の研究が教育実践の場において行われるこ とは, 教育心理学研究の不毛性の克服にとって有力な切 り札となる。そしてそれがスムーズに行われるためには， 教員養成の学部段階において学生が教育心理学の研究法 の基礎をしっかり身につけることが肝要である。とりわ け教育心理学を専修して卒業論文を作成した学生が将来 教育実践の場に臨んだ時に，教育の現場における問題を 取り上げてそれを教育心理学的に解決していく能力を卒 論研究を通じて形成するならば,これまで指摘されて来 た不毛性批判は一掃されよう。

以上のことから期待されるように, 教育実践と深く関 わる教育心理学の研究は, 外部に研究者がいながら教育 現場の人びとの協力を仰いで行うという従来のやり方を 脱却して，研究者自身が教育実践のさなかに身をおいて みずから主体的に行うことが主流となるべきであろう。 研究者が教育実践の場に身を置いて主体的に研究を進め ていこうとするならば，いうまでもなく研究者は児童・ 生徒の教育指導に積極的に関わらなければならず，当然 研究そのものよりも指導それ自体を優先しなければなら ない。医学の研究において患者の生命を守り健康を増進 することが他の何事にもまして重視されなければならな いように, 教育心理学の研究においても児童・生徒の健 やかな成長発達が最優先されるべきなのである。

（3）教育心理学の研究における倫理性

教育実践に深く関わる教育心理学の研究においては, 何よりもまず児童・生徒の人格が尊重されなければなら ない。子どもたちは研究の対象になるために学校に来て いるのではないから, 研究という大義名分のもとに彼ら を思うままに使おうとすることはもはや許されなくなっ た。しかるに教育心理学の研究において，今なおそうし た考えが大手を振って歩いている場合が決してないわけ ではない。

児童・生徒が単なるモルモットではなくて，それぞれ が自分の独自な世界を持ち, みずからの幸せを追求して いる存在であると考えるならば, 教育心理学の研究にお いては彼らの人間性を最大限尊重すべきだという倫理性 の問題が改めて提起されよう。また教師が児童・生徒に 最も良い教育をするために教育心理学の研究を行うのだ という心構えを持っているからといって, 教師の行う調 查や実験がすべてそのまま肯定されるべきであるという 素朴な考えは厳しく吟味されなければならない。児童・ 生徒によかれと思って実験したり調査したことでも, 教 師が予想もできなかったような悪影響を子どもたちに与 
える場合もあるからである。

さて研究における倫理性は一見極めて明白のように思 われるが，個々のケースにおいては非常に複雑微妙であ って，簡単には規定しがたいことに注目すべきであろう。 とりわけ重要なことは，倫理性の具体的な在り方は教師 と児童・生徒との実際的な人間関倸によっても，大きく 左右されるということである。

\section{4 教員養成に対する教育心理学の研究}

（1）教員養成の改善を目指す教育心理学の研究

教員の資質の向上についてしばしば論議されるが，教 員養成において何をどのようにして向上させることが出 来るかについては, 組織的実証的なデータに基づく提案 はほとんどなされていない。したがって教員養成の改善 は単なる個人的な意見ではなくして，合理的な根拠を持 って提唱される必要性が痛感される。 R. O. ブリンカ 一ホフらが教育活動におけるプログラム・エバリュエイ ションの重要性を強調し, 組織的にさまざまな教育活動 について具体的に評価しその改善を図っていることは大 いに参考になるであるう。

このような文脈で教員養成の問題を考えていくと, 今 や教育心理学の研究の重要な課題として教員養成そのも のの在り方を取り上げる必要がある。それはいうまでも なく教員養成の段階で教育心理学をどのように修得させ るかということだけに限定せず，さまざまな学問を専攻 したり，いろいろな教科教育学を修得したりすることを 含めて, 学生にいかなる研究体験を持たせることが教員 養成にとって望ましいかを，長期的・組織的に検討する ことを意味している。なおブリンカーホフらが主張して いるように，教育活動においては従来その評価が片手間 に行われてきたが,よりよい教育を行っていくためには 教育に対する評価を本格的に行うことが肝要である。乙 たがって真剣に教育の在り方を追求していこうとするな らば，学校教育の根幹に関わる教員養成の改善策の検討 に, 費用と労力とを惜しむことなく十分にかけて取り組 むことが肝要となろう。

（2）講義・実験・実習の効率化を図る教育心理学の 研究

教育心理学の研究者が研究に熱心なわりには, 大学に おいて日常行っている教育心理学の教育そのものに対す る教育心理学的アプローチは必ずしも十分には行われて いない。たとえば教育心理学の研究法や統計的処理方法 が重要であると思って熱心に指導すると，学生は教育心 理学の研究は容易なものではないと思い込み，かえって 教育心理学から遠ざかってしまう場合も少なくない。こ うした出来事は学生の側にも原因があることはいうまで
もないが，他方講義や実験実習に当たるわれわれの側に おいても考えなければならない問題があるといえよう。

そもそも教育心理学の講義 1 つを取り上げても, 講義 担当者が受けて来たオーソドックスな講義形態が今なお 踏襲されていることが多く, しかも講義内容が心理学の 專門体系にがっちりと対応した極めて高度のものであっ たりして, 受講生の要求やレベルにマッチしないことが 少なくない。こうした観点からいうと, 教育心理学の授 業研究の必要性が大きくクローズ・アップされるととも に，実験や実習の在り方そのものについても緊急に検討 されなければならない。すなわち教育心理学の実験や実 習が受講生にどのように受け止められているかを的確に 捉えて, 必要な調整をいかにしたら有効に行うことが出 来るか，その方法の開発研究が期待されよう。その際実 際に児童・生徒に接触可能な場をいかにして用意するか が，重大な課題となるであろう。

（3）人間尊重・個性重視の体験の深化を促進する教 育心理学の研究

教育心理学の研究において人間を算なる研究の対象と して物化することなく，1回限りの：生を送る実存的存 在として他の何物によっても替えがたいものであること を実感することが極めて重要である。われわれはこれま で教育心理学においてワン・パターンの研究スタイルを 持ち続け，それを学生などに押しつけて来たが，こうし たことは知らぬ間に人間尊重の気持をスポイルさせてし まったのではなかららか。すなわち教師や研究者が児童 ・生徒を勝手に被験者として用い, 研究のために調查や 実験を一方的に行うことがなんらの反省もなくなされて 来たが，こうした一連の営みは人間性を無視し個性を軽 視する態度を形成させるものであることを反省しなけれ ばならない。

したがって厳しくいうならば，教育心理学の研究はそ れに直接関わりを持つ览童・生徒の幸福や成長をもたら すむのでなければならず，研究が進歩すればいつの日に か子どもたちのためになるであろうというような，漠然 とした思いで安易に行われるべきものではない。すなわ ち研究の対象となる子どものために, 最良の関わりを求 めることが何よりも優先されなければならないことを明 確に認識すべきである。

われわれは教育心理学の研究があくまで教育実践を深 めるための営みであって, 研究論文の作成のためのもの ではないという立場を堅持して，このような研究観を確 立するための方策を組織的に開発するための研究を行わ なければならない。その 1 つの有効な手立てとして，児 童・生徒の生活 と密着した研究の場の設定があげられよ う。日常の生活の中において子どもたちと媣い関わりを 
持ちながら，その発達を促しその指導を図るといら文脈 の中で研究できるという機会と場とを作りえなかったこ とは，大いに反省されるべきではなからうか。

\section{5 教員攁成の立場から見た教育心理学の研究に対す る期待}

\section{（1）教育実践を深める研究}

教育心理学に対する教育現場あるいは関連分野からの 期待は, 何よりも先ず教育実践に直接役立つ研究を積極 的に推進して貪いたいということにある。このような期 待は極めて当然のことであるが，そうした期待に応える ことは必ずしも容易とはいえない。

その重要な理由として挙げられるべきものは, 教育実 践の場において教育心理学の研究を行うことにはさまざ まな障碍が存在するからである。たとえば大学などで研 究に従事している者が学校現場に入りこんで研究しよう とする時には, しばしば教育計画と衝突して容易には協 カが得難いことが多い。他方教育の場にいる学級担任が 教育心理学的研究を行おうとしても, 学級担任としての 仕事をはじめとしてさまざまな雑用その他に追いまくら れ，容易には研究が出来かねるのが現状である。

したがってこのような困難が存在することを十分考虑 しながら，教育実践の場において無理のない形で教育心 理学的研究を推し進めていくことが肝要である。そのた めには研究ということをことさら前面に押し出すことな く，児童・生徒の指導の徹底を図るという，教育本来の 立場を強調することが重要であろう。さらにまた教育の 現場にいる熱心な教育心理学の研究者と大学その他の研 究機関にある研究者とが，いかにして研究の協力を深め ていくかを積極的に検討し，具体的な方策を緊急に開発 しなければならない。

\section{(2) 教育改革に貢献する研究}

明治初年の教育制度の確立, 戦後の $6 \cdot 3$ 制の発足に 続く大きな改革として, 臨時教育審議会の答申が位置う けられようが, これからの教育改革においては何よりも まず，教育の実質を充実することが目指されているが， こうした目標が実際に達成されるためには教育心理学的 研究に支えられた具体的方法が取り上げられなければな らない。從来の教育論議は, 大部分が現状の欠陥の指摘 とそれに関連した思い付き的な改革案の提出に止まって いて, 改革案が本当に欠陥の克服に役立つかどうかの保 証はほとんどなかった。極論すれば現状を変えさえすれ ば欠陥が克服されるはずだと短絡的に考え，そのあげく 現状の変革がますます事態を恶化させてしまうような場 合も決して少なくはなかった。したがってこれからの教 育改革は，現実の教育実践の凟料を組織的に検討して，
そこにおける研究を踏をえて漸次改革していくことが肝 要である。

こうした観点に立って今日の教育改革を見直すならば, さまざまな欠陷を悉く指摘してそれを一挙に解決する抜 本的方策を求めようとすること自体, 教育心理学的アプ ローチに馿染まないものではなかろうか。したがって先 に提出された臨教審の答申内容に即して, それらの提案 を必要に応じて教育の現場に扔いて実践的に逐次検討し て, その成果に基づいて教育の在り方を改善していくと いう，柔軟な構えを持っことが肝要であろう。

こうしたことが実際に行われるためには，教育実践の 場において教師がみずからの教育活動に対してよりよい 成果を挙げることを目指して，積極的に取り組むことが 出来るようにしなければならない。換言すれば教師の創 造性が十分に発揮できるような条件を整備して, 教師が 専門家としてのプライドを持ちながら, みずからの教育 実践を不断に改善し工夫していけるようにしなければな らない。

（3）教師の自己成長性を育てる研究

教育において重要なことは, 優れた教師とは一体いか なる資買の持ち主をいうのか，またそうした資質を伸ば すにはいかなる働きかけが必要なのかということを検討 することである。こうしたことについては教育心理学の 立場から慎重にアプローチ寸ることが肝要であるが, さ しあたっては教師自身が教育実践を研究的に行う過程に おいてみずからの可能性を高めていき, 人間としての自 覚を深めていくことに重点を置いて考えたい。こうした ことはいォば教師の自己成長性といいかえてもよいが, このような自己成長性をいかにして育てることが可能と なるかについて研究していくことが望まれよう。また教 師は教育という人間の成長発達を目指す仕事をしている にもかかわらず，ともするとみずからの人閒的成長を押 し止めてしまうのはなぜかを検討することも必要である。 われわれは教育心理学の研究において, 教師の重要性 について理解して来たつもりであったが，必ずしもそれ に応じた研究は行ってこなかった。その最大の理由は教 師についての研究がともすると教師の価值の值踏みであ ると受け止められ, 過度のアレルギー反応を引き起こし かねなかったという，社会的状況があったからではなか ろうか。したがってわれわれはこのような状況を十分踏 まえ, しかむなお教師の積極的協力を得る方策を探求し て, この問題にアプローチしていく必要があろう。さら にまた, 教師の生活を通じて人間存在の根幹に触れる問 題がいかにしてとりあげられ，いかなるプロセスをたど ってそれに立ち向かうに到るかについて，研究すること が是非とも必要であろう。 